\title{
PENERAPAN ETIKA BISNIS ISLAM DALAM KONTEKS PRODUSEN DAN KONSUMEN: Ke Arah Tanggung Jawab Sosial Perusahaan
}

\author{
Oleb: Mubammad Anas*
}

\section{Abstract}

In fact, business activity neglecting ethics barms consumers and employees as many cases occurred in this country i.e. formalin case, little wage, oil stealing in Kalimantan, industrial cesspool, transaction of stolen wood, etc. Such facts and cases, to etbical perspective, are due to separation between ethics and business which bas a negative impact on buman lives. But, ethics and business are two entities being able to be united as one. According to Islam, business is not only an activity to get financial profit, but also the activity to attain essence of bumanity as implementation of which becomes buman responsibility as creature and caliph in achieving Allab's favor. Therefore, Islam teaches values of business practice such as unity, freedom, responsibility, equality, virtue, and bonesty. It is an valuable teacbing that all parties like producer, consumer, employer, employee, and society must apply business ethics, because this does not deal with vertically producer's responsibility only, but also with existence of business activity its self. Summarily, mutual and harmonious relationship among involved parties in business activity will be constructed, if values of business ethics are beld as fundamental source for their business practice.

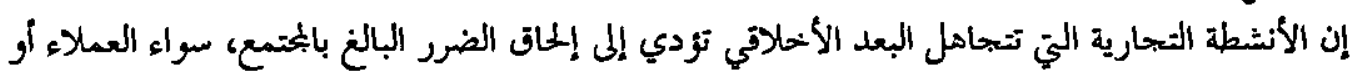
العمال كثريكين رئيسين في تلك الأنشطة. لقد شهات جملة تلك الأنشطة التي لا تعبأ بالبعد الأنحلاقي

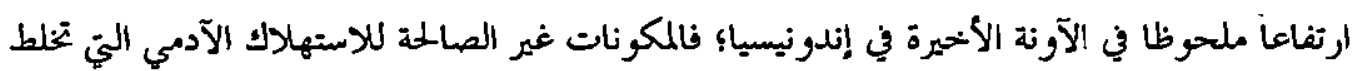
بالأغذية، والمعاملة غمر العادلة للعمال، والاعتداءات المفرطة على البيثة، كلها تبرهن على ذلك. تطرح هذه المقالة يحاولة تفسيرية لأسباب ذلك الارتفاع الملحوظ، فتفسره على أنه يهلدث على أثر الانفعام التام بين البعل التحاري والبعد الأنحلاقي

Keyword: etbics, business, buman responsibility.

\section{A. Pendahuluan}

Hingga kini, etika dan tanggung jawab sosial bisnis masih menjadi perdebatan yang cukup serius di kalangan akademisi dan pelaku bisnis. Kondisi ini, secara umum

• Mahasiswa Pascasarjana UGM Yogyakarta. E-mail annassunya@yahoo.com. 
dapat dipahami, bahwa etika bisnis merupakan penerapan nilai-nilai atau standar moral dalam kebijakan, kelembagaan, dan perilaku bisnis. Ini semua diterapkan untuk meningkatkan good will dalam sebuah perusahaan atau instansi perdagangan lainnya. Kenyataan ini, mendorong etika bisnis sebagai salah satu disiplin keilmuan terapan, yang berhubungan dengan persoalan-persoalan perilaku bisnis dalam berbagai konteksnya, sekaligus menawarkan seperangkat nilai-nilai bisnis dan aturan-aturannya. Hal ini terkait dengan upaya menjembatani persoalan-persoalan yang melingkupinya dengan tanpa menyimpang dari hakikat perdagangan dan nilai-nilai kemanusiaan.

Secara umum bisnis merupakan suatu kegiatan usaha individu atau secara kolektif yang terorganisasi secara sistematis yang berupa penjualan barang dan jasa guna mendapatkan keuntungan dalam memenuhi kebutuhan masyatakat, ${ }^{1}$ atau juga berbentuk suatu lembaga yang menghasilkan barang dan jasa yang dibutuhkan oleh masyarakat. ${ }^{2}$ Proses kegiatan tersebut terkait dengan ranah yang menyangkut hubungan antarmanusia dan berbagai elemen masyarakat. Dari sini lalu muncul dua pandangan yang bertolak belakang menyangkut keterkaitan antara bisnis dengan etika.

Bagi sebagian kalangan, bisnis diartikan sebagai aktivitas ekonomi manusia yang bertujuan mencari keuntungan semata. Aktivitas bisnis dimaksudkan untuk mencari keuntungan sebesar-besamya, karena itu, cara apapun boleh dilakukan demi meraih tujuan tersebut. Sementara prinsip-prinsip moralitas itu sendiri dianggap membatasi aktivitasnya. Konsekuensinya, aspek moralitas sama sekali tidak terkait dengan aktivitas bisnis. Dimensi moralitas dalam persaingan bisnis justru dianggap menghalangi kesuksesannya, yakni yang bertujuan mengeruk keuntungan sebesar-besarnya. Berbeda dengan kelompok yang pertama, kelompok kedua berpendapat bahwa bisnis bisa disatukan dengan etika. Kalangan ini beralasan bahwa etika merupakan alasan-alasan rasional (etika rasional) tentang semua tindakan manusia dalam berbagai aspek kehidupannya, tak terkecuali aktivitas bisnis. Jika dirunut lebih jauh, awalnya, wacana pemikiran etika bisnis ini muncul karena didorong oleh realitas bisnis yang mengabaikan dimensi moral.

Bagi pelaku bisnis dan ahli ekonomi, dengan adanya pandangan demikian, ide mengenai etika bisnis menjadi hal yang problematik. Persoalan itu terletak pada kesangsian apakah moralitas mempunyai tempat dalam kegiatan bisnis dan ekonomi pada umumnya. Dari kalangan ini kemudian dikenal istilah "mitos bisnis

1 Buchari Alma, Pengantar Bisnis, (Bandung: CV Alfabeta, 1997), hal. 16.

${ }^{2}$ Ibid 
moral". 3ecara lebih jelas Ricard T. De George dalam Business Etics, berpendapat bahwa mitos bisnis moral berkeyakinan kalau pelaku bisnis tidak bisa berjalan seiring dengan aspek moralitas. Antara bisnis dan moralitas tidak ada kaitan apa-apa. Dan, karenanya merupakan kekeliruan jika aktivitas bisnis dinilai dengan menggunakan tolak ukur aspek-aspek moralitas. ${ }^{4}$ Dengan bersikap demikian, para penganut mitos ini tidak harus menjadi immoral dalam arti punya kecenderungan melanggat moralitas atau mempunyai sifat moral yang buruk. Mereka hanya sekadar "amoral", dalam arti bebas dari kewajiban mempertimbangkan aspek moral eksplisit dari perilaku mereka dalam aktivitas bisnis. ${ }^{5}$

Dalam perspektif filsafat, dengan meminjam gagasan Wittgeinstein tentang language game, bahwa perilaku dalam organisasi bisnis mempunyai kaedah atau aturan main (rules) yang berbeda-beda, karena aktivitas bisnis adalah form of life atau "permainan" (game) yang berbeda pula dengan perilaku keseharian. Etika bisnis adalah suatu wacana yang berbeda dan tersendiri, bukan sebuah cerminan (mirror) ataupun refleksi dari norma-norma perilaku organisasi bisnis. Wacana bisnis adalah wacana yang berbeda, yang -meminjam bahasa Kuhn- incommensurable (ketidakterbandingan) - dengan wacana etika bisnis.

Di samping itu, pada kenyatannya dalam aktivitas bisnis kini terdapat kecenderungan ke arah tindakan yang mengabaikan prinsip moral. Menurut pandangan dan keyakinan mereka, persaingan dalam dunia bisnis adalah persaingan modal. Pelaku bisnis dengan modal besar berusaha memperbesar jangkauan bisnisnya hingga mengakibatkan para pengusaha kecil (pemodal kecil) semakin terjepit. Adanya praktik monopoli, penimbunan, penyelundupan, penipuan dan seterusnya semakin memperparah kondisi tersebut. Praktik-praktik yang terjadi pada perusahaan-perusahaan besar juga demikian adanya, secara garis besar para pengusaha ini mengabaikan tanggung jawab sosial yang seharusnya dipenuhi. Hubungan perusahaan dengan pekerja dibangun di atas sistem kapitalisme, implikasinya pekerja diperas tenaganya

${ }^{3}$ Ricard T De George, Business Ethics, (New Jersey Hall: Englewood Cliffs, 1986), hal. 5-6. Harus dibedakan dalam konteks ini istilah mitos bisnis amoral dengan mitos bisnis immoral. Dalam mitos bisnis amoral perilaku bisnis dianggap sama sekali tidak dapat dinilai secara moral; kalau dipaksa dinilai maka hasitnya akan netral, dalam arti tidak dapat dikatakan positif ataupun negatif. Sedangkan dalam mitos bisnis immoral, perilaku bisnis dapat dinilai secara moral, namun hasilnya dan bahkan secara aprior dapat diputuskan akan selalu negatif. hal. 49.

'Sony Keraf "Bisakah Bisnis Berjalan tanpa Moralitas", dalam Basis, No. 05-06 (Mei-Juni 1997),

${ }^{5}$ Alois A Nugtoho, "Lima Pandangan Tentang Relevansi Etika Bagi Dunia Bisnis: Sebuah Usaha Pemetaan Awal”, dalam Drijarkara, Tahun XXIII. No. 3. 1997, hal 4-5. 
tanpa dihargai secara layak oleh para pemodal. Ini terbukti dengan minimnya upah atau gaji yang mereka terima, upah yang tidak mencukupi kebutuhan hidupnya, belum lagi perlakuan-perlakuan yang tidak etis juga sering terjadi.

Dalam lingkup hubungan antara perusahaan (produsen) dengan konsumen, perusahaan dengan pebisnis lainnya, atau perusahaan dengan kondisi alam sekitarnya juga demikian adanya. Dengan prinsip mencari keuntungan sebesar-besarnya, tanpa memperhatikan aspek etika, nilai-nilai harmonis dalam kosmos ini, relasi yang terbangun berjalan di luar garis-garis etis. Akibatnya, konsumen dirugikan, pengusaha kecil dan menengah juga demikian. Dan, hubungan yang demikian berjalan dalam ruang kompetitif yang tidak sehat. ${ }^{6}$ Di samping itu praktik kolusi, korupsi, dan nepotisme juga telah memainkan peran penting dalam proses tersebut. Krisis moneter yang berkepanjangan di Indonesia, pada kenyataanya tidak bisa dilepaskan dari proses kegiatan perekonomian yang demikian, yakni menipisnya dan lepasnya nilai-nilai moralitas dalam aktivitasnya. Kenyataan ini kemudian melahirkan anggapan bahwa bisnis adalah "dunia hitam".

Secara lebih spesifik, dalam konteks perusahan, penerapan etika bisnis dihadapkan dengan masalah-masalah yang meliputi proses, people, dan teknologi. Pada tataran prosesnya, etika bisnis bethadapan dengan masalah-masalah klasik seperti cash flow, personal network, quality, competition, dan endurance. Pada people misalnya, etika bisnis dihadapkan dengan persoalan kualitas sumber daya manusia yang belum cukup memadai, motivasi entrepreneur dan keinginan untuk "cepat sukses". Demikian pula dalam teknologi, etika bisnis dihadapkan dengan cepatnya arus perkembangan teknologi, ${ }^{\top}$ yang mensyaratkan keserbacepatan dan efisiensi dalam sistem kerja untuk mencapai suatu hasil yang besar dalam bisnis.

Kondisi yang demikian, menuntut keharusan bagi perusahaan yang ingin tetap eksis dan terus kesinambungan dalam meraih keuntungannya, dihadapkan pada dua pilihan; jika prinsip-prinsip etika bisnis diterapkan, maka bisnisnya akan mengalami kemunduran, sebaliknja jika tidak menetapkan prinsip-prinsip etis maka perusahaan akan mengeruk keuntungan yang besar. Untuk melihat relevansi dan implementasi etika bisnis dalam dunia bisnis, maka secara berurutan akan dipaparkan tiga hal mengenai: hubungan produsen dan kosumen yang meliputi kualitas produk, harga

'Aan Dani Saliswijaya, Himpunan Peraturan tentang Class Action, Jakarta: Gramedia Pustaka Utama, 2004), hal 89.

"Hari Sudarmadji, "Masalah-masalah Etika Bisnis", hand out pada seminar Käian Kritis Strategi Pennuthan Ekonomi Indonesia, dalam rangka 45 tahun FE UGM, 15 September 2000. 
dan iklan; tanggung jawab sosial perusahaan dengan pekerja; dan membangun tanggung jawab sosial dalam dunia bisnis.

Dalam konteks inilah pemikiran etika bisnis Islam lalu dimunculkan ke permukaan, dengan alasan bahwa Islam adalah agama yang mengandung prinsip-prinsip moral yang berkaitan secara langsung dan tidak langsung pada bisnis (tijarab). Dalam diskursus ini, sumbangsih moral yang bersumber dari agama (Islam) tepat kiranya sebab dalam Islam prinsip-prinsip moral bisnis mendapat porsi tersendiri pembahasannya. Islam merupakan agama yang memberikan cara pandang yang terpadu mengenai aturan-aturan dalam berbagai aspek kehidupan, yakni aspek sosial, budaya, ekonomi, sipil dan politik. Ia juga merupakan suatu pengarah bagi seluruh aspek kehidupan, termasuk sistem spiritual maupun perilaku bisnis, ekonomi, dan politik perdagangan.

Memunculkan diskursus etika bisnis Islam ini juga menjawab perdebatan yang menguras energi tentang moral manakah atau siapakah yang layak digunakan? Atau juga sekaligus menjawab atau menjadi jalan tengah antara universalisme etis dan relativisme etis. Etika bisnis Islam dalam tulisan ini disuguhkan untuk menjadi subyek etis yang bersama-sama menjawab kebuntuan selama ini. Dengan demikian, tidak ada alasan untuk menolak hanya karena berasal dari agama tertentu, yang dalam hal ini dari Islam.

\section{B. Mengurai Relasi Etis antara Produsen dan Konsumen}

Produksi atau manufacturing adalah proses yang dilakukan oleh produsen sebagai aktivitas fungsional yang mesti dilakukan oleh setiap perusahaan. Fungsi produsen adalah bekerja menciptakan barang atau jasa yang bertujuan untuk membentuk nilai tambah (value added). Secara ekonomi, aktivitas produksi tersebut meliputi beberapa hal sebagai berikut: produk apa yang dibuat, mengapa dibuat, kapan dibuat, untuk apa dibuat, bagaimana berproduksi, dan berapa jumlah yang dibuat.' Sementara konsumen menempati posisi fundamental yang hakiki dalam bisnis modern. Bisnis tidak akan berjalan tanpa adanya konsumen yang menggunakan produk atau jasa yang ditawarkan oleh produsen. ${ }^{10}$ Slogan the customer is king, bukan hanya bermaksud menarik sebanyak mungkin konsumen, melainkan mengungkapkan tugas pokok produsen adalah menyediakan jasa untuk mengupayakan kepuasan konsumen.

${ }^{8}$ Nidal S Sabri dan M. Hisyam Jabir, "Etika Bisnis dan Akutansi", dalam Sofyan Syafri Harahap, Akentansi Islam, (Jakarta: Bumi Aksara, 1997), hal. 230.

' Muslich, Etika Bisnis Pendekatan Subtantif dan Fungsional, (Yogyakarta: Ekonomia Kampus Fakultas Ekonomi UII Yogyakarta, 1998), hal. 49.

${ }^{10} \mathrm{~K}$ Bertens, Pengantar Etitea Bismis, (Yogyakarta: Kanisius, 2000), hal. 227. 
Meskipun begitu, suatu komoditas jika akan diproduksi haruslah mempertimbangkan alasan sosial kemanusiaan, bahkan sosial-kultural, yakni selain alasan dibutuhkan oleh masyarakat juga perlu dipertanyakan implikasi positif yang ditimbulkannya sebagai akibat diproduksinya suatu komoditas tetsebut. ${ }^{11}$ Di samping itu, produsen juga mempunyai kewajiban untuk menyediakan produk yang aman bagi konsumen, dan harus bertanggung jawab penuh jika terdapat suatu komoditas yang jelek, berkualitas rendah dan merugikan konsumen. ${ }^{12}$

Di sinilah letak pentingnya relasi keseimbangan antara produsen dan konsumen. Sebuah produsen yang berupaya mendayagunakan dan mengembangkan harta bendanya melalui komoditas produk-produknya harus dilakukan dalam kebaikan atau jalan yang tidak menyebabkan kebinasaan diri sendiri dan orang lain. ${ }^{13} \mathrm{Hubungan}$ antara produsen dan konsumen bukanlah hubungan yang tidak seimbang di mana produsen mempunyai kebebasan untuk meraih keuntungan sebesar-besarnya yang dapat merugikan konsumen. Sebaliknya hubungan keduanya harus berada dalam keseimbangan, dalam arti demi menghindari pemusatan kekuasaan ekonomi dan bisnis dalam genggaman produsen semata.

Islam secara jelas tidak membenarkan upaya-upaya dan praktik penumpukan sumber daya ekonomi pada segelintir kelompok saja. ${ }^{14}$ Al-Qaraḍawi menegaskan bahwa Islam mengajarkan sistem pasar bebas, akan tetapi Islam tidak mentolerir penimbunan barang, manipulasi atau memainkan harga. Meskipun begitu, Islam memperbolehkan mengontrol harga dalam upaya memenuhi kebutuhan masyarakat luas serta mencegah praktik-praktik keserakahan. ${ }^{15}$

Secara formal, hubungan antara produsen dan konsumen bukanlah termasuk hubungan kontraktual, yakni hak yang ditimbulkan dan dimiliki oleh seorang ketika mamasuki sebuah perjanjian dengan pihak lain. ${ }^{16}$ Hubungan ini berbeda dengan

${ }^{11}$ Muslich, Etika., hal. 51.

${ }^{12}$ Produsen harus bertanggung jawab bila komoditas produksinya mengakibatkan kerugian bagi konsumen. Jika terjadi kerugian pada konsumen, maka produsen harus berani untuk menggantinya dengan produk yang baru. K. Bertens, Pengantor., hal. 232.

${ }^{13}$ Misalnya surat al-Baqaarah (2): 195.

${ }^{14}$ Al-Hasyr (49): 7.

${ }^{15}$ Choirul Fuad Yusuf, "Etika Bisnis Islam: Sebuah Persepektif Lingkungan Global", Ulumul Qur'an, No. 3, Vol. VIII, Tahun 1997, hal. 18.

${ }^{16}$ Dalam hubungan kontmaktual kedua belah pihak dapat dianggap baik dan adil jika mengetahui hakikat dan kondisi persetujuan yang disepakati, tidak ada pihak yang dengan sengaja memberikan fakta yang salah, tidak dilakukan dengan paksaan. Lihat, A. Sonny Keraf, Etika Bisnis Tuntutan dan Relevansinya, (Yogyakarta: Kanisius, 1998), hal. 184. 
hubungan kerja sama dalam suatu bisnis. Pada umumnya, hubungan produsen dan konsumen merupakan hubungan interaksi secara anonim, masing-masing pihak tidak mengetahui secara pasti mengenai pribadi-pribadi tertentu kecuali hanya berdasarkan dugaan yang lebih kuat. Lebih rumit lagi hubungan antara keduanya seringkali diperantarai oleh sekian banyak agen dan penyalur. ${ }^{17} \mathrm{Hal}$ demikian bukan berarti bahwa di antara keduanya tidak punya hak dan kewajiban, karena dalam kenyataannya hubungan mereka merupakan interaksi sosial yang menentukan adanya hak-hak dan kewajiban masing-masing pihak yang berfungsi sebagai pengendali. Pengendali ini meliputi aturan moralitas yang tertanam dalam hati sanubari masing-masing dan aturan hukum serta saksi-saksinya.

Kedua perangkat pengendali itu, terutama lebih tertuju pada produsen. Hal ini disebabkan karena konsumen, dalam hubungannya dengan produsen, seringkali berada dalam posisi lemah dan rentan untuk dirugikan. Dalam kerangka bisnis sebagai sebuah profesi, konsumen sesungguhnya membayar produsen untuk menyediakan barang yang dibutuhkannya secara profesional. ${ }^{18}$ Kerena ita dalam hubungannya dengan persoalan ini, produsen harus memperlakukan konsumen dengan baik. Hal ini secara moral tidak saja merupakan tuntutan etis, melainkan juga sebagai syarat mutlak untuk mencapai keberhasitan bisnis.

Nilai aksioma prinsip kesatuan etika bisnis Islam dapatlah dipahami dalam konteks ini, yakni ketika antara produsen dan konsumen terjadi konsistensi dan keteraturan yang menyeluruh. Produsen tidak akan berlaku serakah, karena pada hakikatnya harta yang dimilikinya merupakan amanah, ${ }^{19}$ dan konsumen pun demikian, tidak serta merta menginginkan kepemilikan yang lebih dari kebutuhannya, sehingga merugikan konsumen lainnya.

Namun demikian, walaupun konsumen digelari raja, tetapi dalam kenyataanya seringkali ia berada dalam posisi yang serba terbatas. Ia tidak mempunyai "kuasa" untuk menentukan pilihan bebas terhadap apa yang akan ditentukan. Kadangkala daya beli yang dilakukan terjadi dengan keterpaksaan. Ia tidak sanggup menggungkapkan preferensi yang sesungguhnya. Apa yang telah dibelinya belum tentu sesuai dengan keinginannya. $\mathrm{Hal}$ ini dikarenakan, misalnya karena kurangnya informasi tentang produk, tidak ada saluran bagi pengaduan atas terjadinya semisal penipuan

\footnotetext{
${ }^{17}$ Ibid, hal. 185.

${ }^{18}$ Ibid., hal. 186-187.

${ }^{19}$ Al-Kahfi (18): 46.
} 
dan lain-lain. Padahal Islam jelas melarang segala bentuk kecurangan, penipuan, pemalsuan dan berbagai tindakan merugikan dalam bisnis. ${ }^{20}$

Menurut Ibn Taimiyah, jaminan atau garansi atas konsumen merupakan bagian dari tanggung jawab seorang yang diangkat sebagai mubtasib, ${ }^{21}$ yakni seorang ahli (agama dan ekonomi) yang bertugas khusus untuk mengawasi sistem perekonomian secara komprehensif. Secara tingkas tugas mubtasib meliputi: Pertama, Memenuhi dan mencukupi ketersediaan kebutuhan-kebutuhan di pasar. Kedua, Pengawasan terhadap industri yakni mengawasi standarisasi produk. Ketiga, Pengawasan atas jasa untuk menjaga praktik-praktik penyelewengan profesi-profesi seperti dokter, ahli farmasi, guru, dan sebagainya. Keempat, Pengawasan atas perdagangan yang meliputi pengawasan ukuran, timbangan, kualitas produk dan lain-lain yang kesemuanya bermuara pada tujuan menjamin agar konsumen tidak dirugikan. ${ }^{22}$

Berdasarkan aksioma kehendak bebas, mestinya konsumen dapat memberlakukannya dalam konteks menentukan pilihan dan keputusan atas suatu produk yang dibutuhkannya. Secara fundamental manusia mempunyai sifat kehendak yang bebas, namun kehendak bebas yang bertanggung jawab. Hanya saja, adanya struktur jaringan produsen dengan berbagai rantai bisnisnya terkadang membatasi kebebasan dan kehendak konsumen. Sebaliknya produsen menjadi leluasa dalam memberlakukan rencana-rencana dan strateginya untuk mendapatkan keuntungan dari konsumen sebanyak-sebanyaknya.

Kesadaran tentang kewajiban tehadap konsumen sampai sejauh ini belum banyak terimplikasikan dalam dunia usaha. Pada tahun 1962, presiden John F Kennedy mengusulkan kepada konggres mengenai special massage on protecting the costumer interest, yang kemudian ditetapkannya empat hak yang dimiliki oleh konsumen, yakni: the right to safety, the right to be informed, the right to choose, the right to be beard. Di samping itu, konsumen juga memilki hak atas lingkungan hidup (jaminan bahwa komoditas tidak merusak lingkungan sekitat) dan hak konsumen atas pendidikan (yaitu hak

\section{${ }^{20}$ Choirul Fuad Yusuf, "Etika, hal. 18}

${ }^{21}$ Lembaga mubtasib disebut Hisbah. Lembaga ini sejak masa Rasulullah sudah ada kendati Iebih banyak dipergunakan pada masa selanjutnya. Lembaga ini mempunyai fungsi pertama, sebuah sistem yang secara umum digambarkan pelaksanaan kebajikan dan kewajiban oleh muhtasib dan berkaitan dengan aspek agama dan yuridis dalam pengurusannya. Kedua, digambarkan sebagai praktek dan teknik pemgawasan secara detail, termasuk di dalamnya melakukan control atas prdoduk, perdagangan, tuntutan admisnistratif, kualitas serta standar produk. Lihat, A. A. Islahi, Konsepsi Ekonomi Ibmu Taimibyah, terj. Anshari Tayyib, (Surabaya, PT. Bina Ilmu, 1997), hal. 238.

22 Ibid., hal. 240-242. 
kosumen dididik untuk dapat melakukan kritik atas suatu komoditas). Di Indonesia, semua hak tersebut telah masuk dalam undang-undang tentang Petlindungan Konsumen sejak 1999, termasuk di dalamnya hak-hak lain seperti hak untuk mendapatkan advokasi serta perlindungan dan hak untuk mendapatkan ganti rugi. ${ }^{23}$

Tanggung jawab lain yang harus dimiliki oleh produsen adalah menjamin adanya kualitas produk-produknya pada satu sisi dan harga yang adil serta kebenaran iklan sebagai media informasi utama pada sisi lainnya. Kualitas produksi dimaksudkan sebagai jaminan bahwa produk suatu komoditas sesuai dengan apa yang dijaminkan oleh produsen, baik melalui informasi maupun iklan. Kualitas produk sesungguhnya bukan hanya merupakan tuntutan etis tetapi juga suatu syarat untuk mencapai kesuksesan dalam bisnis. ${ }^{24}$ Konsumen yang fanatik terhadap suatu komoditas lebih disebabkan oleh tetbuktinya kualitas komoditas tersebut. Salah satu bentuk contoh jaminan kualitas adalah pengemasan dan pemberian label pada kemasan yang sesuai dengan kenyataan produk tersebut. Pemberian label ini misalnya meliputi kehalalan suatu produk, batas pemakaian, bahan-bahan asal dan lain-lain.

Harga merupakan buah hasil perhitungan dari faktor-faktor seperti, biaya produksi, biaya investasi, promosi, pajak ditambah laba yang wajar. ${ }^{25}$ Suatu harga yang adil dalam sistem ekonomi pasar merupakan hasil dari daya-daya yang diperankan oleh pasar, yakni hasil dari tawar-menawar sebagaimana dilakukan oleh pembeli dan penjual tradisional. Harga bisa disebut adil jika telah disetujui oleh kedua belah pihak yang melakukan transaksi. Akan tetapi dalam realitasnya tidak bisa dikatakan bahwa pasar merupakan satu-satunya prinsip untuk menentukan harga yang adil.

Kondisi ini terjadi disebabkan oleh beberapa faktor: Pertama, Hampir dapat dipastikan bahwa pasar tidak pernah sempurna, khususnya menyangkut sistem ekonomi kapitalis, sebuah sistem ekonomi yang tetkonsentrasi pada bebetapa pengusaha yang punya modal besar. Kedua, Para konsumen seringkali berada dalam posisi lemah dalam memperhitungkan harga serta lemah dalam menganalisis faktor-faktor yang mempengaruhi perubahan harga. Dan ketiga, Cara menentukan harga berdasarkan mekanisme pasar dapat mengakibatkan fluktuasi harga terlalu tinggi. ${ }^{26}$

Tingginya harga terjadi, khususnya menyangkut ketidakadilan dalam pemberian harga, disebabkan oleh empat faktor yaitu: 1). Penipuan. Hal ini terjadi, misalnya,

${ }^{23}$ K Bertens, Pengantar., hal. 228-230.

24. Ibid, hal. 240.

${ }^{25}$ Ibid, hal. 241.

${ }^{26}$ Ibid, hal. 242. 
disebabkan adanya kolusi yang dilakukan oleh produsen dan distributor dalam penetapan harga (conspiratorial price ficing). 2). Ketidaktahuan pihak konsumen atau kurangnya informasi yang jelas mengenai harga tersebut. 3). Penyalahgunaan kuasa, misalnya permainan harga atau banting harga oleh pengusaha besar yang mengakibatkan pengusaha kecil dibuat bangkrut. 4). Manipulasi emosi, yakni memanipulasikan emosi seorang untuk memperoleh untung yang besar atau menggunakan kondisi psikologi orang yang sedang berkabung ${ }^{27}$

Adanya ketidakadilan harga jelas bertentangan dengan nilai-nilai aksiomatika kesatuan, keseimbangan, kebajikan, pertanggungjawaban dan kebenaran. Harga yang tidak adil jelas-jelas menjadi pemicu ketidakseimbangan pasar. Harga yang tidak adil juga tidak akan membawa kepada kebijaksanaan umum, tetapi sebaliknya justru akan mengakibatkan timbulnya kondisi-kondisi yang tidak menentu, sehingga mendorong munculnya kezaliman-kezaliman dalam praktik bisnis.

Salah satu wujud konkret dalam upaya memberi informasi yang akurat kepada para konsumen adalah melalui penayangan iklan. Iklan merupakan salah satu pengejewantahan dari aspek pemasaran yang menetapkan pasar sebagai orientasi. Pasar merupakan mitra sasaran dan sumber penghasilan yang dapat menghidupi dan mendukung pertumbuhan perusahaan. ${ }^{28}$ Pada fungsinya iklan mempunyai tugas memberikan informasi yang lengkap dan ukuran kepada masyarakat tentang sesuatu yang dipromosikan. Kelengkapan dan keakuratan informasi yang disampaikan meliputi kegnnaan barang, komposisi dan kombinasi elemen yang dilupakan dalam pembuatannya, sifat atau karakter barang dan keterangan-keterangan lainnya tentang barang tersebut $^{20}$

Dati aspek ini dapat dipahami bahwa iklan merupakan media komunikasi antara produsen dan pasar, antara penjual dan calon pembeli yang betisi pesan-pesan. Pesan dalam iklan dapat dibedakan menjadi dua fungsi: fungsi informatif dan fungsi persuasif yang bertujuan promosi untuk maksud mempengaruhi calon konsumen. Tercampurnya kedua unsur ini dalam periklanan menjadikan persoalan etis muncul ke permukaan. Sebah, pada kenyataannya, dunia periklanan banyak dilatarbelakangi oleh suatu ideologi yang tersembunyi, yakni ideologi konsumerisme. ${ }^{30}$

\footnotetext{
${ }^{2 \pi} I b i d$, hal 243-244.

${ }^{2}$ Mustich, Etika, hal 37.

2 Ibid, hal 42
}

30 Secara umum dipahamī bahwa iklan lebih banyak bernilai fungsi persuasif, karenanya tidak mempungai reputasi baik sebagai pelindung dan pejuang kebenaran. Kerapkali iklan justru berisi bal-hal 
Karena itu landasan etika bisnis yang harus diperhatikan dalam periklanan adalah prinsip kesatuan, pertanggung jawaban dan kehendak bebas, kebajikan dan kebenaran. Dalam proses membuat dan menyebatkan suatu informasi iklan harus terdapat suatu keyakinan bahwa tidak ada satu aktivitas pun yang lepas dari pengawasan zat ilahi. Meskipun penyampaian informasi produk disampaikan dengan kteativitas yang beragam, tetapi hal dibatasi oleh tanggung jawab dalam bentuk horizontal dan vertikal sekaligus. Suatu kebebasan yang tidak terkendali pasti akan membawa dampak negatif, walaupun dalam jangka pendek mungkin menguntungkan. Demikian pula nilai kebenaran harus dijunjung tinggi untuk memperhatikan suatu tujuan luhur dalam bisnis.

Kiranya, pembahasan etika bisnis dalam periklanan ini paling tidak menyangkut dua hal: 1. Mengenai persoalan kebenaran dalam iklan. 2. Persoalan manipulasi publik yang tidak sedikit dilakukan dalam dunia periklanan. Jika dalam iklan tidak terdapat unsur kebohongan dan penipuan maka dapat dikatakan bahwa iklan tersebut mempunyai nilai kebenaran. Kebohongan dalam menginformasikan suatu produk yang dilakukan secara sengaja dengan maksud agar dipercaya oleh orang atau masyarakat. Lebih dari itu, di era teknologi informasi kini, semisal penggunaan teknik media visual, teknik ilusi optik dengan mudah dapat melakukan kebohongan sekaligus penipuan untuk mempetlihatkan gambaran suatu produk yang istimewa tanpa cacat. ${ }^{31}$

Demikian pula persoalan manipulasi publik dengan periklanan menjadi hal yang krusial. Manipulasi dalam pengertian mempengaruhi kemauan orang lain sedemikian rupa sebingga ia menghendaki atau menginginkan sesuatu yang sebenarnya tidak dipilih oleh orang tersebut. Karena dimanipulasi, seseorang tidak dengan secara sadar mengikuti motivasi yang tidak berasal dati dirinya melainkan dari pihak luar. Dari sisi ini manipulasi merupakan hal yang tidak etis karena melanggar otonomi dan kebebasan manusia. ${ }^{32}$

Oleh karena itu, untuk menanggulangi akibat-akibat demikian secara lebih dini, penanggulangannya harus dilakukan dengan dua metode sekaligus. 1. Mengembangkan kesadaran para pelaku yang terlibat dalam dunia periklanan terutama mengenai ekses-ekses negatif yang telah ditimbulkannya. 2. Menghidupkan media-media

yang jauh dari kenyataan dengan maksud agar menarik minat calon pembeli sebanyak-banyaknya. Karena itu tidak jarang bahwa bisnis periklanan memamerkan suatu suasana hedonistis dan materalistis. Lihat, K Bettens, Pengantar., bal 263-266.

${ }^{31}$ Ibid, hal. 264-269.

${ }^{32}$ Ibid, hal. 270-273. 
pengontrolan terhadap periklanan semisal media wacth atau corruption watch, yang dibangun atas dasar upaya pengejawantahan nilai-nilai etika bisnis.

Dengan demikian, dalam seluruh rangkaian dan proses bisnis baik sejak niat memulai suatu bisnis, dalam proses produksi, pengemasan produk, proses periklanan produk, penetapan hatga dan penjaminan kualitas suatu produk, kesemuanya tidak lepas dari prinsip-prinsip bisnis dan etika bisnis secara menyeluruh. Demikian etika bisnis memberikan relevansi dan tuntutannya sehingga bisnis bukan lagi merupakan dunia yang kering dari nilai-nilai etika itu sendiri.

\section{Tanggung Jawab Sosial Perusahaan}

Secara garis besar, terdapat tiga pandangan mengenai tanggung jawab sosial perusahaan. a). Para manajer secara jujur memfokuskan diri bagi kepentingan perusahaan. Dengan demikian ia merupakan agen untuk mencapai kesejahteraan para pekerja perusahaan. b). Para manajer mempunyai tugas untuk menyeimbangkan kepentingan pokok dari para pelaku perusahaan. c). Para manajer bertanggung jawab dalam melayani masyarakat, yakni dengan program-program sosial yang menguntungkan masyarakat dan hubungannya dengan pekerja. ${ }^{33}$

Dari ketiga pandangan di atas, tokoh seperti Milton Friedman memaknai tanggung jawab sosial perusahaan seperti pada pandangan pertama dan kedua. Ia beralasan bahwa tanggung jawab sosial perusahaan bertujuaan untuk memperbaiki citra dari kegiatan mencari untung. Pendapat ini merupakan kelanjutan dari berbagai pandangan bahwa bisnis tidak perlu mewujudkan tujuan-tujuan lain selain tujuan ekonomi. ${ }^{34}$ Bila pemahaman tentang tanggung jawab sosial perusahaan dipahami seperti demikian, maka dapat dibayangkan berbagai akibat-akibat negatif yang ditimbulkan oleh kebijakan-kebijakan suatu perusahaan terhadap lingkungan sosial sekitarnya.

Tanggung jawab sosial perusahaan adalah tanggung jawab moral perusahaan terhadap masyarakat. Tanggung jawab ini dapat diarahkan mulai dari dirinya sendiri, karyawan, perusahaan lain, lingkungan sosial bahkan sampai kepada Negara. Untuk melihat secara jelas tentang tanggung jawab sosial perusahaan ini harus dibedakan antara tanggung jawab ekonomis dan tanggung jawab sosial. Tanggung jawab ekonomis biasanya diukur dengan keberhasilan kinerja perusahaan dan laba yang

${ }^{33}$ George A. Steiner and John F. Steiner, Buriness, Government and Sociely A Managerial Perspectif, (Singapure: Mc Graw Book Co, 1994), hal. 109.

${ }^{34} \mathrm{~K}$ Bertens, Pengantar, hal. 292-294. 
didapat. Berbeda dengan perusahaan-perusahaan milik permerintah, seperti perusahaan umum Kereta Api, walaupun dari sisi ekonomis selalu rugi, tetapi karena alasan tanggung jawab sosial perusahaan ini tetap dipertahankan. Dari pandangan ini maka dapat ditarik benang merah sementara bahwa tanggung jawab sosial berada di luar tanggung jawab ekonomi sebuah perusahaan.

Berdasarkan pada prinsip ajaran "persamaan" (equality), menurut Islam, seorang manager harus memperlakukan pembayaran, pengembangan dan perlakuan lainnya terhadap karyawannya berdasarkan prinsip kejujuran dan keadilan. ${ }^{35}$ Dalam Islam, Allah memerintahkan untuk menyampaikan amanat kepada yang berhak menerimanya, serta menetapkan hukum (aturan) berdasarkan rasa keadilan. Berdasarkan QS. 60: 8 tentang perintah berlaku adil dan menghormati keyakinan pekerja, kemudian QS. 4: 149 tentang perintah untuk menghormati privacy dan memaafkan serta merahasiakan kesalahan atau cela orang lain, maka seorang manager perusahaan harus melakukan pembayaran gaji atau upah secara adil.

Pekerja harus dibayar secara adil dan tepat waktu, lantaran upah adalah hak atas keringat atau tenaga yang telah dikeluarkan. Islam mengutuk segala bentuk eksploitasi. Besarnya upah yang diberikan harus sepadan berdasarkan keadilan, sehingga tidak merugikan kedua belah pihak (perusahaạn dan pekerja). ${ }^{36}$

Tindakan etis lain yang menyangkut hubungan perusahaan dengan pekerja adalah keharusan bagi keduanya untuk menghormati privacy masing-masing. Pekerja harus menjaga nama baik, kerahasiaan. Sebaliknya perusahaan juga harus menjaga nama baik, rahasia dan kejelekan pekerja. Singkatnya, kedua belah pihak berkewajiban membangun hubungan dialogal dan manusiawi, menghindari suasana hubungan konfliktual yang dapat merugikan kedua belah pihak. Hubungan antara perusahaan dan pekerja harus didasarkan pada nilai dasar $i \underline{b s a ̂ n}$ (kebaikan) serta rasa tanggung jawab, baik tanggung jawab kepada Allah maupun kepada manusia. ${ }^{37}$

Tanggung jawab ini sendiri merupakan suatu prinsip. dinamis yang berhubungan dengan keseluruhan perilaku manusia dalam hubungannya dengan masyatakat ataupun situasi. Suatu tanggung jawab bahkan mempunyai kekuatan dinamis untuk mempertahankankan kualitas kesetimbangan dalam masyarakat. Dalam hubungan

${ }^{35}$ Choirul Fuad Yusuf, "Etika, hal. 17.

${ }^{36}$ Sebagaimana yang disabdakan Nabi: Berikakan upah pekerja sebelum kering keringatnya. Lihat. Abu Abdillah Muhammad bin Yazid al-Qazwini Ibn Mâjah, Sunan Ibn Măjab 16 (Semarang: Toha Putra, t.t), II: 84.

${ }^{37}$ Choirul Fuad Yusuf, 'Etika, hal. 17. 
dengan tanggung, jawab sosiali suatur perusahaan, aksioama tanggung jawab dijabarkan menjadii suatu pola petilaku perusahaan tertentu. Suatu tanggung jawab untuk memperbaiki kualitas lingkunganı sosiall misalnya menyebabkan perilaku perusahaan tidak sepenuhnya bargantung, kepada' penghasilannya sendiri; melainkan bergantung pada faktor-faktor: lainnya.

Dari konsepsi tanggung,jawab, itu, maka ia mempunyai sifat berlapis ganda dan terfokus baik pada tingkatan mikro (individu) maupun tingkat makro (organisasi dan sosial), yang, kedua-duanya harusi dil'kukan! secara bersama-sama secara seimbang dalam segala bentuk dan ruang; lingkupnya. Antara pemilik, manajer, karyawan, masyarakat dan sosial bahkan dengan Negara.

Dengan aksioma pertanggungjawaban inii, maka! secara mendasar akan mengubah perhitungan bisnis perusahaan, karena segala sesuatunya harus mengacu pada keadilan. Dalam perspektif aplikasinya, tanggung, jawab sosial dapat dilihat dari dua sisi, yaitu sisi positif dan sisi negatif: Secara positif perusahaan dapat melakukan kegiatan yang tidak membawa keuntungan ekonomïs dan semata-mata dilangsungkan demi kesejahteraan masyarakat atau salahy satu kelompok masyarakat. Sedangkan dari sisi negatiff perusahaan dapat menahan diri untuk tidak melakukan kegiatankegiatan tertentu, yang, sebenamya menguntungkan datii sisi bisnis tetapi akan:merugikan masyarakat atau sebagian masyarakat.

Dalam kenyataannya, ketika menyimak sejarah industri misalnya, terdapat beberapa perusahaan yang besar dan memperoleh nama baik bukan semata-mata karena bidang bisnis tetapii apa yang, disebut karya amal ${ }^{381}$ Karya amal inilah yang justru. dapat membangun suatu citra di lialangan masyatakat secata mendalam. Hal ini membuktikan bahwa bagusnya kinerja! sebuah perusahaan bukan hanya dibuktikan dengan kinerja melainkan bethubungan erat dengan kerja-kerja sosial yang diberikannya kepada masyarkat secara riel sebagai implementasi dari tanggung jawab sosial perusahaannya pada satu sisi dan! berakibat pada memperkokoh suatu citra positif pada sisi lainnya. Dengan demikian kerja-kerja sosiall dalam lingkup yang luas tidak bertentangan dengan tujuan ekonomis jangka panjang, suatu bisnis, tetapi sebaliknya sangat mendukung:

Oleh karena itur, organisasi bisnis dituntut aktif terlibat dalam upaya mengembangkan derajat tanggung jawab sosial'nya'.. Karena organisasi bisnis memiliki posisi

${ }^{38}$ Contoh yang konkret adalahı Cameg̈e yang, banyakmembantu lembaga pendidikan dari 28000 perpustakaan. Selain itur Bill Gate termasuk juga! dalam: pembangunan teknologi informasi pada lembaga-lembaga pendidikan dan sosiall Lihat; K Bertens, Pengantar, hal 299-302 
strategis untuk membangun masyarakat sekitarnya, maka ia memerlukan sejumlab alat untuk memacu dan meningkatkan derajat kepekaan dan tanggung jawab sosialnya, agar mampu mencipta keseimbangan kesejahteraan hidup masyarakat. Oleh karena itu, terdapat dua pendekatan yang dapat ditempuh:

Pertama, pendekatan eksplisit, yang dapat ditempuh dengan cara mengembangkan kode etik, memperkuat dukungan etik, meningkatkan kualitas proses seleksi dan pelatihan etik, serta mengembangkan sistem ganjaran (reward system). ${ }^{39}$ Kedua, pendekatan implisit, yang dapat diwujudkan melalui beberapa upaya: (1). Mengubah struktur budaya, dengan cara menanamkan nilai dan norma dalam masyarakat. Islam sebagai agama yang sarat dengan nilai dan norma yang dapat mengatur segenap aspek kehidupan akan mudah melakukan perubahan budaya masyarakat, dan (2). Mengembangkan saluran komunikasi informal untuk mengetahui pesan yang berkaitan dengan peristiwa tindakan amoral dalam rangka perbaikan. ${ }^{40}$ Dengan demikian upaya perbaikan dalam menempatkan etika bisnis Islam dalam konteks global dapat terwujud.

\section{Penutup}

Dalam Islam, bisnis dan etika bukan merupakan dua bangunan yang terpisah, melainkan satu kesatuan struktur. Dalam keterpaduan tersebut, Islam memberikan bangunan paradigma etika dalam berbisnis, yakni bisnis yang dibangun di atas nilainilai aksioma; kesatuan, kehendak bebas, pertanggungjawaban, kesetimbangan (keadilan), dan kebenaran (kebajikan) dan kejujuran.

Hubungan produsen dengan konsumen yang meliputi kualitas dan keamanan komoditas, serta keadilan harga merupakan proses bisnis yang berkesinambungan yang tidak boleh lepas dari nilai-nilai etika. Penerapan etika bisnis Islam dalam hal ini bukan hanya terkait dengan tanggung jawab produsen kepada Allah, akan tetapi hal ini juga menyangkut kepercayaan konsumen atas komoditas yang diproduksinya. Tentu secara umum menyangkut eksistensi produsen atau perusahaan untuk tetap bisa bertahan di dunia perbisnisan.

Tanggung jawab sosial perusahaan terhadap pekerja juga membutuhkan etika bisnis Islam sebagai landasan etis untuk menjadi rambu-rambu yang disepakati bersama dalam mencapai hubungan yang harmonis antara keduanya. Perusahaan harus memenuhi kewajibannya dengan memberi gaji yang layak untuk kehidupan pekerja dan keluarganya. Di samping juga harus menghormati keyakinan para pekerja itu

${ }^{39}$ Choirul Fuad Yusuf, 'Etika, hal. 21

${ }^{40} \mathrm{Ibid}$. 
64 Millab Vol. VIII, No. 1, Agustus 2008

sendiri. Agar hubungan yang harmonis tercapai, para pekerja juga harus memenuhi kewajibannya untuk bekerja secara baik dan penuh tanggung jawab. Tanggung jawab sosial perusahaan juga terkait dengan kondisi sosial masyarakat serta alam sekitat. Perusahaan juga harus melakukan kerja-kerja sosial untuk kemakmuran masyatakat dan menjaga keseimbangan produksinya dengan alam sekitar. 


\section{DAFTAR PUSTAKA}

A. Nugroho. Alois. 1997. "Lima Pandangan Tentang Relevansi Etika Bagi Dunia Bisnis: Sebuah Usaha Pemetaan Awal"; Driyarkara, Tahun XXIII. No. 3.

"Abdillah Muhammad bin Yazid al-Qazwini Ibn Majah. Abu. tt. Sunan Ibn Mäjab" 16 Semarang: Toha Putera.

Bertens. K. 2000. Pengantar Etika Bisnis, Yogyakarta: Kanisius.

Buchari. Alma. 1997. Pengantar Bisnis, Bandung: CV Alfabeta.

Dani Saliswijaya. Aan. 2004. Himpunan Peraturan tentang Class Action, Jakarta: Gramedia Pustaka Utama.

De George. Ricatd T. 1986.Business Ethics, New Jersey Hall: Englewood Cliffs.

Fuad Yusuf. Choirul. 1997. "Etika Bisnis Islam: Sebuah Persepektif Lingkungan Global”, Ulumul Qur'an, No. 3, Vol. VIII.

George A. Steiner and John F. Steiner. 1994. Business, Government and Society A Managerial Perspectif, Singapure: Mc Graw Book Co.

Islahi. A. A. 1997. Konsepsi Ekonomi Ibnu Taimiyjah, terj. Anshari Tayyib, Surabaya, PT. Bina Ilmu.

Keraf. Sonny. 1998. Etika Bisnis Tuntutan dan Relevansinya, Yogyakarta: Kanisius. . Mei-Juni 1997. "Bisakah Bisnis Berjalan tanpa Moralitas”, Basis, No. 05-06

Muslich. 1998. Etika Bisnis Pendekatan Subtantif dan Fungsional, (Yogyaikarta: Ekonomia Kampus Fakultas Ekonomi UII Yogyakarta.

Nidal S Sabri dan M. Hisyam Jabir. 1997. “Etika Bisnis dan Akutansi”, dalam Sofyan Safri Harahap, Akuntansi Islam, Jakarta: Bumi Aksara.

Sudarmadji. Hari. 2000. "Masalah-masalah Etika Bisnis", Hand out pada seminar Kajian Kritis Strategi Pemulihan Ekonomi Indonesia, dalam rangka 45 tahun FE UGM, 15 September. 